\title{
Digital Society: Regulatory and Institutional Support of Electronic Governance in Modern Realities
}

\author{
Dmytro Arabadzhyiev ${ }^{1}$, Yana Popovych ${ }^{1 *}$, Iryna Lytvynchuk $^{2}$, Kanat Bakbergen ${ }^{3}$ and Yurii Kyrychenko ${ }^{1}$ \\ ${ }^{1}$ National University «Zaporizhzhya Polytechnic», 69063 Zaporizhzhya, Ukraine \\ ${ }^{2}$ Polissia National University, 10008 Zhytomyr, Ukraine \\ ${ }^{3}$ Kazakh-German polytechnic college, 160400 Kentau, Republic of Kazakhstan
}

\begin{abstract}
The article highlights the opportunities for the introduction of e-government in the institutional system of society on the basis of digital, information and communication technologies (on the example of Ukraine). It develops the concept of digitalization from the point of that information, knowledge and communication technologies constitute the system of social and legal infrastructure of society. It demonstrates that digital society forms the basis of the safety of modern globalized world, expressed in quality indicators of "e-government". It is proved that E-government in the legal system of the country involves: first, creating conditions for interaction between government and citizens through the use of modern information and communication technologies; secondly, the availability and openness of state registers; third, the introduction of e-democracy tools. It is determined that there is a steady tendency in the Ukrainian society to spread e-government tools in the legal sphere through the provision of administrative information services as well as the use of e-democracy technologies. It is also justified that potential of e-democracy technologies is strong enough to create conditions for e-government in legal sphere through technological and technical support of legal services, improving the level of computer iteracy of the population, increasing accessibility and openness of public information.
\end{abstract}

\section{Introduction}

Modern information era in global social development of mankind requires rapid response to challenges in the social, economic, political and legal space. In a broader sense, a new type of society is being formed, which is based on the concept of the information society. "A new society is a society of mental labor based on the application of human knowledge to everything that is produced and to ways how it is produced. New ideas will be the main source of wealth" [5, p.264-265]. Information society is a society where information has become the most important resource, the production and distribution of which serve as socially and personally significant economic, political and cultural activities. In this society information is perceived 1) as a commodity, 2) as a means of managing the individual and society, 3) as an instrument of power, 4) as a weapon in economic and political struggle.

The creation of the population social protection effective system in Ukraine is one of the priority tasks of the state social policy, provides for the social services system modernization for the population in accordance with new socio-economic challenges, the population dominant needs, the development of the information society, requires the introduction of innovative technologies for the social services provision, based on dissemination and application of egovernment and administration methodology.

The analysis shows that the issue of the social services system effectiveness for the population has been and is the subject of scientific research and heated debate in sociological discourse. One of the main approaches to research is the structural-functional approach, the central problem of which is the institutionalization of the providing social services system (R.Merton, N.Smelzer, T.Parsons). No less important is the role of subjective orientation theories (M.Weber, N.Luhmann, J.Habermas, E.Giddens, P.Bourdieu).

It can be stated that there is an important scientific problem, which lies in the contradiction between the spread of social services' modern practices in the system of electronic services, spread in the most developed societies of the world, on the one hand, and the lack of available knowledge about the plurality of forms, ways of using and mechanisms for implementing social services in the system of electronic services in the social protection field in Ukraine at the present stage of social and technological transformations, on the other hand.

At the stage of transition to an information society, it is no longer the problems of further technicalization of society, as it was believed a few years ago, that come to the fore, but the problems of its intellectualization, the creation and implementation of new social technologies based on the effective use of the main society - knowledge strategic resource.

"Digital government" by virtue of global trends and practices of public administration is defined as a system that consumes or as a state organization of electronic government, a separate management model 
at the level of the state, created using information and communication technologies. Considering the above, digital government is viewed as a form of governance or as an organization of governance and thanks to which communicative, information technologies are used to increase efficiency in accessibility, transparency in public administration and a complex of administrative and social services for people and the population as a whole, for the state and for business. There are some problems have been identified that impede the implementation and development of egovernment in the social services system for the population as the provision of e-social services: firstly, the lack of a scientifically grounded methodology for the e-social services provision, their list, standardization, mechanisms and social subjects of their provision, which is fixed and regulated at the legislative level; secondly, the lack of material, technical and technological equipment of social protection institutions and social services for the population and uneven access to the Internet and modern computer facilities of certain territories and categories of the population; thirdly, the absence of an advanced training system and social workers education in the social services provision in a remote form.

While in previous types of society the main share of capital was concentrated in the production of material resources necessary for the life of human society, in the information society this share is concentrated in the production and distribution of information. Another definition was proposed by the Commission of the European Union: "information society is a society in which human activities are carried out on the basis of the use of services provided through information technology and communication technologies" (EUC, 1993).

The interpretation of the concept was developed by scientists who formulated the definition of the information society as an ideal market society, in which education and information shape every person who aware of collective constraints; moreover, as a society of ideal planning, where the centre receives true communication from the members concerning their goals and desires and forms its own structure and position accordingly [9]. Information and participation in management are developed as a single process. In the information society group plans reflect social and cultural aspirations to a greater extent than before. At the same time, the external pressure will increase. In these circumstances, "only the government, which has decent information, will be able to promote development and guarantee the independence of the country" [9].

On the basis of the information society background M. McLuhan introduces as a leading concept "electronic society", the defining elements of which are information and communication technologies and information networks. From that moment we can introduce creating a digital analogue of society - "esociety".

Thus, the concept of information society where knowledge and information and communication technologies constitute the system of social and legal infrastructure for the interaction of state and people (in particular through the use of electronic communication systems) is the basis of modern realities. In modern management theory and practice information technologies are embodied in the concepts of "egovernment" and "e-government", which are implemented in the legal system of modern society.

Therefore, the purpose of the article is to identify opportunities for the implementation of e-government into the legal system of Ukrainian society on the basis of digital and communication technologies.

The methodological basis of the study are general scientific methods of cognition of social phenomena and processes (analysis, synthesis, generalization, classification) and sociological methods of obtaining empirical data (mass and expert sociological survey). The empirical basis of the study are the results of:

1) a mass sociological survey among the population of Ukraine aged 18 years $(n=1000$, November 2020). The sample is quota, randomized, distributed by sex, age, region and place of residence (city and countryside). The error is not more than $2.2 \%$;

2) expert survey among legal scholars and civil servants $(n=200$, November 2020).

\section{Materials and Methods}

Theoretical and methodological approaches consider the concept of "e-government" as a service, as a state electronic organization and as a model of public administration based on the use of information and communication technologies. For instance, some experts consider e-government as the application of information and communication technologies in public administration combined with organizational change and new skills, aimed to improve the quality of public services and democratic processes as well as to strengthen support for public policy (EUC, 1993). Others defines e-government as a way of organizing state governance with the help of local information networks and segments of the global information network, which ensures the functioning of certain services in real time and makes daily communication with official institutions as simple as possible [10, p.131].

The legal framework for e-government is predominantly declarative in nature, as the relevant regulations are strategic and, in some cases, directly related to the implementation of the Association Agreement with the EU. However, the introduction of e-government technologies at an appropriate level and, accordingly, their legal support is not instantaneous and requires both time and significant efforts related to the adaptation of the existing Ukrainian legislation.

On the website of the Supreme Council of Ukraine there are normative legal acts on informatization (since 1993). In February 1998, as is known, the Law of Ukraine "On the National Informatization Program" and the Law of Ukraine "On the Concept of the National Informatization Program" were adopted.

Among the normative documents adopted before this date, one should mention the Decree of the 
President of Ukraine "On the state policy of informatization of Ukraine" dated May 31, 1993 No. 186/93. Decree of the President of Ukraine "On the establishment of the National Agency for Informatization" dated March 13, 1995 No. 206 / 95 Decree of the President of Ukraine "On measures to ensure the activities of the National Agency for Informatization" dated May 27, 1995 No. 390/95 Decree of the President of Ukraine "On the Regulation on the State Communications Committee of Ukraine" dated December 11, 1997 No. 1352/97, as well as Resolution of the Cabinet of Ministers of Ukraine "Informatization Issues" dated August 31, 1994 No. 605, Resolution of the Cabinet of Ministers of Ukraine "On the National Agency for Informatization Issues under the President of Ukraine" dated July 10, 1995 No. 505.

So, in matters of state policy of informatization, there is a leading, organizing role of the President of Ukraine. The government, pursuant to the abovementioned decrees, has been implementing the policy of informatization.

Actually, the first mention of the term "electronic government" in domestic legislation is contained in government documents, namely in the order of the Cabinet of Ministers of Ukraine "On Approval of the Concept of Formation of a System of National Electronic Information Resources" dated May 5, 2003 No. 259-r and in the Report of the Cabinet of Ministers Ukraine Supreme Council of Ukraine on the state and development of informatization in Ukraine in 2003 (one of the directions of development of the regulatory framework of the sphere of informatization in 2003 was the introduction of electronic management technologies).

At the beginning of 2007, the Law of Ukraine "On the Basic Principles of Development of the Information Society in Ukraine for 2007-2015" was adopted. Subsequently, by the order of the Cabinet of Ministers of Ukraine dated August 15, 2007 No. 653-r, an action plan was approved to fulfill the tasks provided for by this law.

In the period after the approval of the Concept for the Development of Electronic Governance in Ukraine, a number of important regulatory and legal acts were adopted. So, in Article 3 of the Law of Ukraine "On Information" (as amended in 2011), the electronic government development is defined as one of the main directions of the state information policy implementation.

With the aim of introducing into the public administration bodies activities a system of electronic interaction between executive authorities in 2011-2012 The Cabinet of Ministers of Ukraine adopted the Order "Issues of implementing the system of electronic interaction of executive authorities" dated December 28, 2011 No. 1363-r and the Resolution "Some issues of electronic interaction between executive authorities" dated July 18, 2012 No. 670.

In 2012, the Government of Ukraine approved the Concept for the Creation and Operation of an Information System for Electronic Interaction of State Electronic Information Resources, which was to become the main component of electronic governance. Later, on July 11, 2013, by order of the Cabinet of Ministers of Ukraine No. 517-r, an action plan for its implementation was approved, and already in 2016 - a regulation on the specified system.

On May 15, 2013, by order of the Cabinet of Ministers of Ukraine No. 386-r, the Strategy for the Development of the Information Society in Ukraine, calculated until 2020, was approved. Electronic governance is defined as one of the main directions of its implementation.

In the context of Ukraine's aspirations to integrate into the European Union, the introduction of European norms and standards for the state information policy implementation is of particular importance. Thus, within the framework of the implementation of the Association Agreement, Ukraine must ensure the comprehensive development of e-government in accordance with European requirements. In turn, by the Decree of the President of Ukraine "On the Strategy for Sustainable Development" Ukraine - 2020 "No. 5/2015 dated 12.01.2015. The e-government development is defined as one of the top-priorities of reforming the public administration system.

The adoption of the Concept for the e-government development in Ukraine (hereinafter - the Concept) at the end of 2010 in no way contributed to the understanding of both state bodies and ordinary citizens of what exactly the term "e-government" means and which components need to be developed. This, in turn, led to a significant lag of Ukraine from the global rates of electronic government development.

According to the order of the Cabinet of Ministers of Ukraine No. 649-r dated September 20, 2017, the new text of the Concept for the electronic government development in Ukraine was approved. The purpose of the Concept is to determine the directions, mechanisms and timing of the effective e-government system formation in Ukraine to ensure the interests and needs of individuals and legal entities, improve the public administration system, increase the competitiveness of the ability and stimulate the socio-economic development of the country. Then, when the previous concept was mostly declarative.

Since in the current legislation e-government is considered as a component of the informatization field, the e-governance technologies introduction is possible through the widespread use of digital technologies, thereby ensuring the public services modernization and the development of interaction between government, citizens and business as the main stakeholders of relations. That is, there is a digitalization of public relations.

The concept provides for the introduction of electronic governance using digital technologies in three key areas: management services modernization and the development of interaction between government, citizens and business; public administration modernization; management of the electronic governance development, thereby improving the quality and effectiveness of the task's implementation in this area. 
E-government is part of a more global phenomenon - e-governance. The strategic goal of e-government is to support and simplify the management process for all stakeholders: government, citizens and businesses through information and communication technologies. In Ukraine the Concept of e-Government Development defines the following: "Digital government" - can be called the government of public administration, helps the development, accessibility and transparency of local and national authorities that used information technology, communication technologies, contributing to the creation of a type of state that did not exist until now, the purpose of which is to fulfill the population needs [4]. It means that e-governance is a combination of e-government with e-democracy, in particular the use of information and communication technologies to accelerate democratic processes [2, p.121].

Scientists define the following stages of building egovernance in most countries: 1) "e-governance" ("government on-line» $(G O L)$ ), which is carried out on the basis of the use of information and communication technologies; 2) "electronic government" ("egovernment") as information interaction of public authorities and society with the use of ICT; 3) "egoverning". At this stage, the maximum combination of the two components "e-governance" and "edemocracy" is possible, which leads to improved interaction in the whole society in the processes of state decision-making, state regulation and provision of universal government services [6].

The rapid development of communication technologies, information technologies of our time, the development of the Internet makes it possible in the legal aspect to use various methods of obtaining or providing services in the field of electronic form, namely those that are most popular when creating a state, that is focused on the transition to a digital state and electronic services on the part of the state: efficiency, openness and transparency of public administration, to provide remote administrative and legal services for people, society, state and business.

At present, in world practice, the following channels or their combinations are mainly used for the provision of legal services: personal reception of citizens; telephone (voice) service and call-centres; web portal; Email; SMS and other messaging services; mobile portal (mobile site); mobile application; social networks; online legal services; intermediaries based on public-private partnership. A special place among these channels is occupied by the tools of e-democracy - submission of e-petitions, electronic proposals for the adoption of legislation (public discussions), e-voting. Thus, we can observe the slow digitalization of the legal system, which concerns both - individual branches of law and the interaction between the state and society as a whole.

Leading world experience is important for the success of e-government in developing countries (especially in the field of law). According to many experts, the Estonian experience of implementing egovernment is the most acceptable.

The rapid development of the digital society in Estonia was provoked by the use of secure data exchange systems and the implementation of electronic identification - eID, which led to the promotion of the following electronic services: «e-Banking» (1996), «eTax Board» (2000), «e-Cabinet» (2000), «m-Parking» (2000), «e-Geoportal» (2001), «e-School» (2003), «eTicket» (2004), «e-Police» (2005), «e-Notary» (2006), «e-Business» (2007), «e-Health» (2008), «ePrescription» (2010), «e-Residency» (2014). Currently, Estonian citizens have access to such electronic services as e-taxes, e-health, e-banking, e-school, eelections, ID-ticket [8]. It demonstrates the active phase of e-government implementation in this country. Most of the population was so positive about the concept of e-government that the traditional forms of public affairs in Estonia become "a thing of the past" [1], which indicates the priority of e-government in the social, economic, political and legal spaces.

Currently, a number of electronic services for the provision of legal services operate in Ukraine as well. Thus, the Cabinet of Electronic Registers was created on the website of the Ministry of Justice of Ukraine, among which the following can be distinguished: State Register of Real Property Rights, Unified State Register of Legal Entities and Individual Entrepreneurs, Register of Public Associations, Unified State Register of Court Decisions, Unified register of notaries, etc.

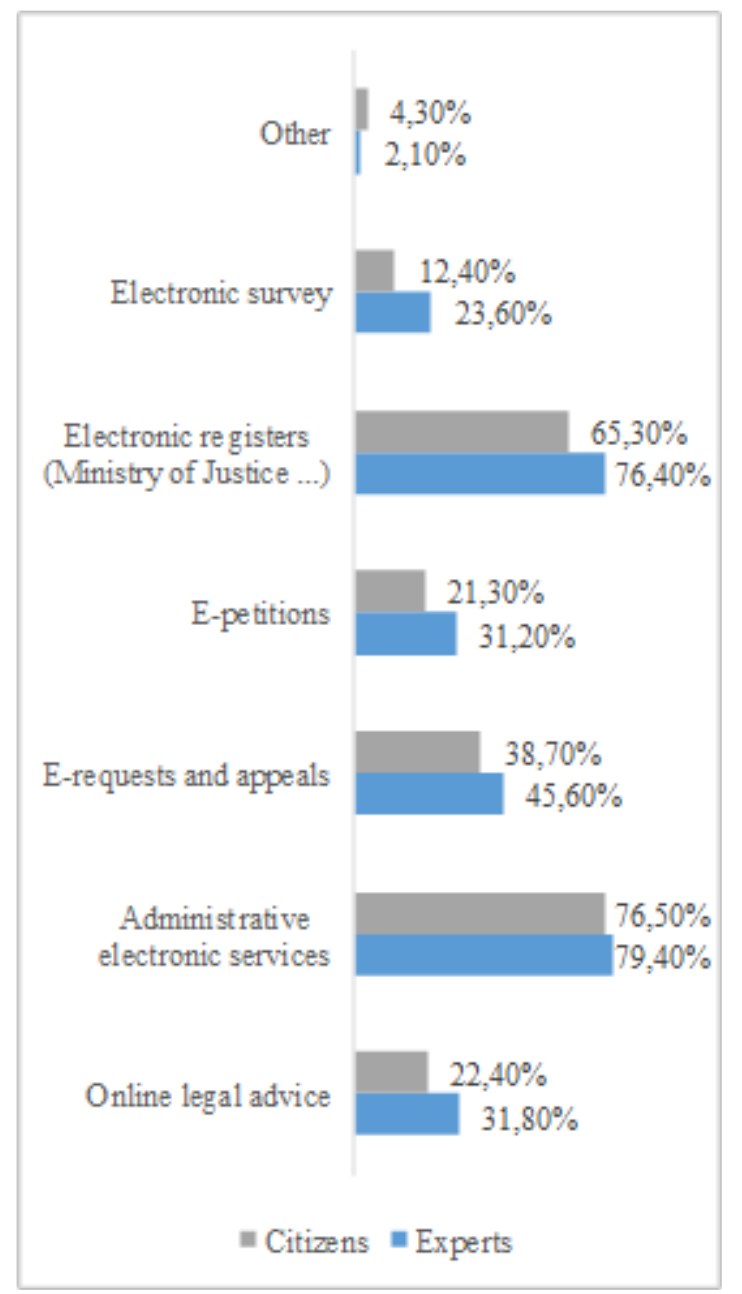

Fig. 1. Evaluation of the most accessible and widespread egovernment tools in the legal system (multiplied options were allowed) 
To identify opportunities for the use of egovernment tools in the legal system of Ukraine, there were conducted sociological and expert surveys (November, 2020).

The survey revealed a higher-than-average level of awareness about the possibility of providing (receiving) electronic services in the legal field among experts and citizens (more than 50\%). Fig. 1 presents an assessment of the most accessible and widespread egovernment tools in the legal system of Ukraine.

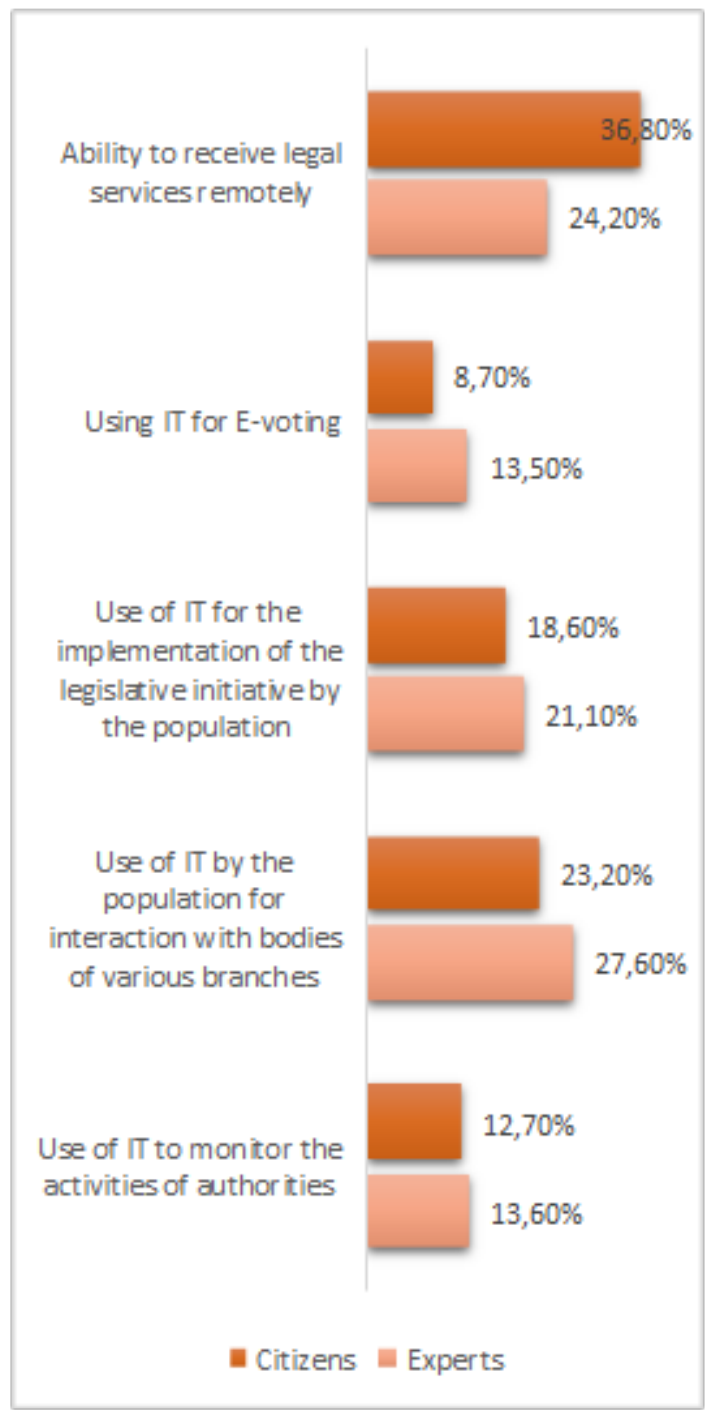

Fig. 2. Definition of e-democracy as a field of application of e-government in the legal system of the state (multiplied options were allowed)

In general, the assessments of experts and citizens coincide in a hierarchical structure. The most common and available are administrative electronic services, electronic registers, inquiries and appeals. The rapid development of modern information and communication technologies and the Internet already allows the use of various forms of providing and receiving electronic services in the legal field, which are becoming widespread due to the state policy of digitalization of public services ("state in smartphone"). Among them the most popular services are electronic forms, obtaining information on court decisions, property rights register etc. Therefore, the survey indicators show that more than half of the surveyed citizens already had such experience (54\%). In particular, it was proposed to define the essence and substantive features of e-democracy as a field of application of e-government in the legal system of the state (Fig. 2).

The results of the survey among citizens indicate the importance of e-democracy to receive open and accessible electronic legal services. Interesting figures we get according the use of ICT in voting various levels: for experts they are the possible tools of edemocracy in Ukrainian society, but citizens often are less familiar with international experience of electronic forms of voting. It should also be noted that only $20 \%$ of respondents believe that the essence of e-democracy is the use of ICT in the implementation of legislative initiatives by citizens, which may threaten to discredit this form of democracy (widespread disregard for public opinion, petitions, appeals, etc.).

Fig. 3 presents the factors for optimizing the implementation of e-government in the legal system of the state.

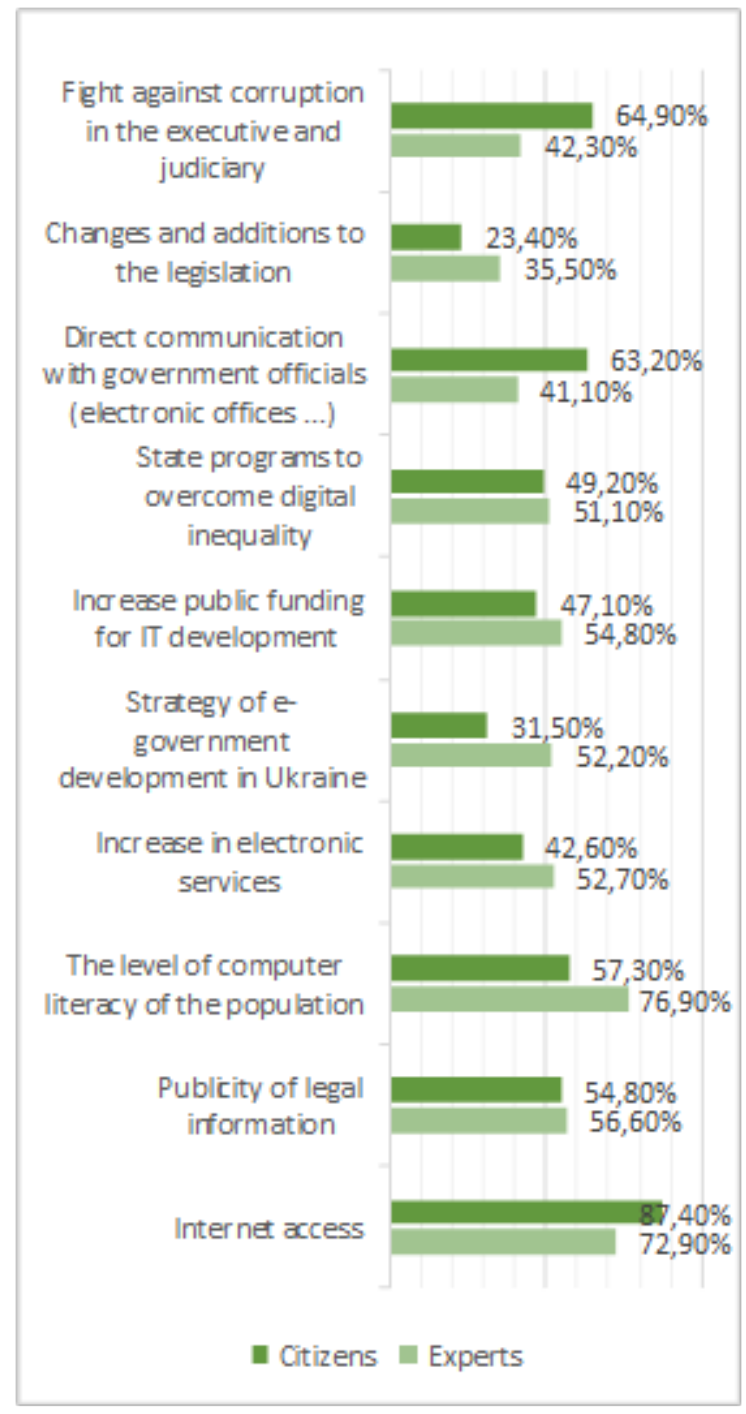

Fig. 3. Factors for optimizing the introduction of egovernment in the legal system of the state (multiplied options were allowed) 
For the interviewed citizens, the factors of optimizing the process of implementation of digital technologies into the legal system of the country are: accessibility and coverage of the Internet, the fight against corruption and secrecy of government, the possibility of free interaction with the authorities, improving computer literacy; for experts - improving the computer literacy of the population, the availability and coverage of the Internet, expanding the scope of electronic public services, the formation of a state strategy for the development of e-government in Ukraine.

\section{Conclusions}

Based on the results of theoretical and empirical analysis, we have made the following conclusions.

1. The concept of information society, in which knowledge, information and communication technologies constitute the system of the state social infrastructure (including the interaction of state and society through the use of electronic communication systems) is the basis of modern development models and finds practical application in e-government algorithms.

2. E-government in the legal system of the country involves: first, creating conditions for interaction between government and citizens through the use of modern information and communication technologies; secondly, the availability and openness of state registers; third, the implementation of e-democracy tools.

3. There is a steady tendency in the Ukrainian society to spread e-government tools in the legal sphere through the provision of administrative informationservices, as well as the use of e-democracy technologies. In those circumstances factors for optimizing the introduction of digital technologies in the legal system of the country are: 1) technological and technical support for the provision of legal services (Internet coverage of territories, overcoming digital inequality, etc.); 2) raising the level of computer literacy of the population and forming a positive perception of the e-government and e-democracy concept; 3) increasing the level of accessibility and transparency to public information.

The study also shows that the legal component of digital activity in the context of social assistance in Ukraine is weak, which makes it recommended to legalize "electronic social services" in the legal field as soon as possible.

For the implementation of electronic services and their provision in the legal field, it is necessary to develop a conceptual system-activity model of the system for the electronic social services provision, the main dimensions of which are: 1) scientific and methodological dimension (scientific substantiation of the social services provision in electronic and online form, development of standards for the electronic services provision, etc.); 2) regulatory dimension (legislative support and regulation of the providing electronic social services process); 3) institutional and organizational dimension (the creation of the social services organizational structure in the e-government system at all levels of the social protection sphere functioning - national, regional, local) 4) measurement of material and technological support for the electronic social services provision; 5) measurement of social and public management of the system for the electronic social services provision; 6) measuring the formation of a criteria system for the social efficiency of social services as the electronic social services provision. Based on research, it is possible to improve that will increase the electronic social services system efficiency, the e-government development in the field of social services in general areas, through the implementation of a set of social mechanisms, the owner of which provides appropriate optimization solutions for remote social services. the following groups: 1) social and managerial mechanisms (organizational and managerial, institutional, normative); 2) mechanisms of social partnership (social and information-communication interaction of subjects of social services provision); 3 ) mechanisms of social marketing (social advertising, PR-technologies in the social sphere); 4) educational and personnel mechanisms (educational and training programs for the population, training or refresher courses for social workers).

Based on the study, it can be argued that the effectiveness of the functioning of the system for the electronic social services provision, the electronic management development in the field of social services for the population in general, depends on the implementation of a set of social mechanisms, which in fact represent the directions for optimizing the implementation of social services in a remote form, among which are highlighted the following groups: 1) social and managerial mechanisms (organizational and managerial, institutional, regulatory) 2) mechanisms of social partnership (social and information and communication interaction of subjects of the social services provision); 3) mechanisms of social marketing (social advertising, PR technologies in the social sphere) 4) educational and personnel mechanisms (educational and training programs for the population, training or refresher courses for social workers).

\section{References}

1. E. Arkhipova, N. Dmitrenko. Experience of egovernment implementation in Estonia and its introduction in Ukraine. A young scientist, 11 (2015)

2. N. Dragomiretska. Theoretical analysis of communicative activity of a civil servant: monograph. Odessa (2005)

3. T. Lower. Theoretical principles of e-government. Investments: practice and experience, 20 (2017)

4. On approval of the Concept of e-government development in Ukraine: Order of the Cabinet of Ministers of Ukraine № 649-r dated 20.09.2017 URL: http: // zakon.rada.gov.ua. 
5. D. Tapscott D. Electronic-digital society society: pros and cons of network intelligence. K.: ITN Press; M.: Refl-buk (1999)

6. M. Shvets, R. Kalyuzhny, V. Tsymbalyuk, V. Gavlovsky. Ukraine on the way to the information society. Legal informatics, 1 (2011)

7. E-government Council of Europe URL: http://www.coe.int/T/E/Com/Files/Themes/evoting/definition.asp

8. e-Estonia-e-Governance in Practice. URL: http://ega.ee/wp-content/uploads/2016/06/eEstonia-e-Governance-in-Practice.pdf (2016)

9. S. Nora, A. Minc. The Computerisation of Society. A Report to the President of France. Cambridge, L. (1980)

10. Pogrebnyak. E-government and e-governance: concepts and principles of functioning. Law and innovation, №3, 7 (2014)

11. Law of Ukraine "On Social Services" (Supreme Council of Ukraine (VVR), № 45, st.358. http://zakon.rada.gov.ua/cgi-bin/laws/main.cgi ? nreg $=966-15$ (2003) 